\title{
Lipoprotein apheresis is an optimal therapeutic option to reduce increased $\mathrm{Lp}(\mathrm{a})$ levels
}

\author{
V. J. J. Schettler ${ }^{1}$ C. L. Neumann ${ }^{2}$ C. Peter ${ }^{3}$ T. Zimmermann ${ }^{3} \cdot$ U. Julius ${ }^{4} \cdot$ B. Hohenstein ${ }^{4}$ E. Roeseler ${ }^{5}$ \\ F. Heigl ${ }^{6} \cdot$ P. Grützmacher ${ }^{7} \cdot$ H. Blume ${ }^{8} \cdot$ R. Klingel $^{9} \cdot$ A Vogt $^{10} \cdot$ Scientific Board of GLAR for the German \\ Apheresis Working Group
}

Published online: 5 March 2019

(C) The Author(s) 2019

\begin{abstract}
Background Lipoprotein(a) ( $\operatorname{Lp}(\mathrm{a}))$ is a genetic risk factor for cardiovascular disease (CVD) and is associated with the induction and sustaining of atherosclerotic cardiovascular diseases (ASCVD). Since $2008 \mathrm{Lp}$ (a) along with progressive CVD has been approved as an indication for regular lipoprotein apheresis (LA) in Germany. The German Lipoprotein Apheresis Registry (GLAR) has been initiated to provide statistical evidence for the assessment of extracorporeal procedures to treat dyslipidemia for both LDL-cholesterol (LDL-C) and Lp(a). The GLAR now allows prospective investigations over a 5-year period about annual incidence rates of cardiovascular events. Here Lp(a) patients (LDL-C $<100 \mathrm{mg} / \mathrm{dl}$; $\mathrm{Lp}(\mathrm{a})>60 \mathrm{mg} / \mathrm{dl}$ or $>120 \mathrm{nmol} / \mathrm{l})$ showed the same reduction of major coronary $(83 \%)$ and non-coronary events $(63 \%)$ as had been formerly shown in the Pro(a)LiFe study. However, Lp(a) is not only an apolipoprotein(a) (apo(a)) and LDL-C containing particle, which is covalently bound to a LDL-C core by a disulphide bridge. The composition of this particle, inter alia containing oxidized phospholipids, gives pro-atherosclerotic, pro-inflammatory, and pro-thrombotic properties, inducing atherosclerotic processes mainly in the arterial wall. However, recent investigations have shown that a reduction of inflammatory settings without LDL-C or Lp(a) reduction may reduce ASCVD events. Lipoprotein apheresis (LA) could not only reduce LDL-C and Lp(a) in parallel, but also different inflammatory and coagulation parameters. In summary lipoprotein apheresis is not only anti-atherosclerotic, but also anti-inflammatory and anti-thrombotic and therefore an ideal treatment option with respect to the shown reduction of major adverse coronary events (MACE) and major adverse non-coronary events (MANCE) by reducing Lp(a) levels.
\end{abstract}

Keywords Lipoprotein apheresis $\cdot$ Lipoprotein (a) $\cdot$ Cardiovascular disease $\cdot$ Coronary artery disease $\cdot$ Major coronary events $\cdot$ Major non-coronary events $\cdot$ Inflammation $\cdot$ Prevention

This article is part of the special issue " $L p(a)$ - Update 2018"

V. J. J. Schettler

v.schettler@nz-goe.de

1 Center of Nephrology Göttingen GbR, An der Lutter 24, 37075 Göttingen, Germany

2 BRAVE-Benefit for Research on Arterial Hypertension, Dyslipidemia and Vascular Risk and Education e. V, Göttingen, Germany

3 BioArtProducts GmbH (B.A.P.), Rostock, Germany

4 Extracorporeal Treatment and Apheresis Center, Department of Internal Medicine III, University Hospital and Faculty of Medicine Carl Gustav Carus, Technische Universität Dresden, Dresden, Germany
5 Center for Nephrology, Hypertension, and Metabolic Diseases, Hanover, Germany

6 Medical Care Centre Kempten-Allgäu, Kempten, Germany

7 Department of Medicine II for Nephrology, Hypertension and Vascular Risks, AGAPLESION Markus Hospital, Frankfurt, Germany

8 Scientific Institute for Nephrology (WiNe), Düsseldorf, Germany

9 Apheresis Research Institute, Stadtwaldgürtel 77, 50935 Cologne, Germany

10 Medizinische Klinik und Poliklinik 4, Universität München, Munich, Germany 


\section{Introduction}

Atherosclerotic cardiovascular diseases (ASCVD) are the main cause of morbidity and mortality in western countries [1]. Since 2009 multiple investigations have provided more evidence that $L p(a)$ is an independent risk factor [2]. This evidence was obtained from genetic, Mendelian randomization, and epidemiologic investigations [2, 3]. $\mathrm{Lp}(\mathrm{a})$ is complex due to its composition of a low-density lipoprotein cholesterol (LDL-C) particle, in which apolipoprotein B is covalently bound to apolipoprotein(a), which contains different kringles with various characteristics [4]. These structures are responsible for its pro-atherosclerotic, pro-inflammatory, and pro-thrombotic properties, inducing ASCVD or calcific aortic valve stenosis (CAVS) [2]. Therefore, because of the different compositions $L p(a)$ properties are not similar or comparable to LDL. Consequently, drug-induced $L p(a)$ reduction might be less successful than could be shown for LDL-C.

Until now, little is known about the effect of reducing $\mathrm{Lp}$ (a) and the outcomes with respect to the development and progress of ASCVD or CAVS [2]. In the last few decades a lot of investigations could not differentiate between the effect of Lp(a) and LDL-C on atherosclerosis development due to ineffective LDL-C-lowering therapies. The demand for a therapy is increasing because of the knowledge that Lp(a) can induce early ASCVD or CAVS independently of LDL-C levels [5]. Whereas statins are discussed as increasing Lp(a) levels [6], some investigations showed a reduction of $\mathrm{Lp}$ (a) induced by nicotinic acid [7]. However, a reduction of major cardiovascular events (MACE) could not be shown for nicotinic acid. Due to the negative results of the Atherothrombosis Intervention in Metabolic Syndrome with low HDL/HIGH Triglycerides (AIM-HIGH) trial, nicotinic acid has been withdrawn from the German market [8].

The monoclonal antibodies to proprotein convertase subtilisin/kexin type 9 (PCSK9) alirocumab and evolocumab reduced LDL-C by up to a mean of $60-70 \%$ from baseline, which corresponds to a reduction of MACE $[9,10]$. In addition, both PCSK9 inhibitors (PCSK9i) showed a reduction of $L p(a), 20-30 \%$ in low or moderate $L p(a)$ levels $<50 \mathrm{mg} / \mathrm{dl}(<120 \mathrm{nmol} / \mathrm{l})$, but less than $20 \%$ in higher Lp(a) levels [11]. Although outcome studies for both PCSK9i exist, data showing a reduction of $L p(a)$ corresponding to MACE reduction are not available until now.

Since 2008 Lp(a) accompanied by progressive cardiovascular disease has been approved as an indication for lipoprotein apheresis (LA) in Germany. The term "progressive cardiovascular disease" was not clearly defined by the Federal Joint Committee (G-BA), the highest decisionmaking body of the joint self-government of physicians, dentists, hospitals and health insurance funds in Germany.
Members of the German Apheresis Working Group filled the gap: LA therapy is indicated, when high Lp(a) levels $(>60 \mathrm{mg} / \mathrm{dl}(120 \mathrm{nmol} / \mathrm{l}))$ in combination with normal LDL-C levels $(<100 \mathrm{mg} / \mathrm{dl}(<2.6 \mathrm{mmol} / \mathrm{l}))$ induced untypically early cardiovascular damage [12]. In addition, LA may be also indicated when at a particular time the atherosclerosis process is in such an advanced state that further progress will be life-threatening or fatal. In this situation LA therapy is the only therapeutic way to achieve significant $L p(a)$ reduction and a better prognosis.

However, the Canakinumab Anti-inflammatory Thrombosis Outcomes Study (CANTOS) has provided convincing evidence of interleukin- 1 beta as a target, whose neutralization by a selective antibody reduces major cardiovascular events without affecting LDL-C or Lp(a) levels [13]. This provides strong evidence in support of the inflammation hypothesis and will certainly stimulate research in this area and open the way for novel therapy in high-risk patients following myocardial infarction. Recent investigations have shown that a reduction of inflammatory settings without LDL-C or Lp(a) reduction may reduce ASCVD events [14]. The LA procedure could not only reduce LDL-C and Lp(a) in parallel, but also various inflammatory and coagulation parameters $[15,16]$.

In a recent publication of the Pro(a)LiFe study, the 5-year prospective follow-up results confirm that LA has a lasting effect on prevention of cardiovascular events in patients with increased Lp(a) levels [17]. For this issue a database query of the German Lipoprotein Apheresis Registry (GLAR) was performed to verify the findings from the Pro(a)LiFe study [18].

\section{Material and methods}

\section{Data queries and evaluation}

The latest database query for this publication was performed in April 2018. All data were collected in the time period 2012-2017 and analyzed using the statistics software SigmaStat (SigmaStat 4.0; Systat Software Inc., San Jose, CA, USA).

Additionally, patient data were analyzed with respect to incidence rates of major coronary events (MACE) and major non-coronary events (MANCE) 2 years before and prospectively $2-5$ years after initiation of LA treatment. This current data pattern gives the optimal sample size for statistical evaluation. For this investigation, a specific data term for $L p(a)$ patients' selection was created: $\mathrm{Lp}(\mathrm{a})>60 \mathrm{mg} / \mathrm{dl}(>120 \mathrm{nmol} / \mathrm{l}) ; \mathrm{LDL}-\mathrm{C}<100 \mathrm{mg} / \mathrm{dl}$ $(<2.6 \mathrm{mmol} / \mathrm{l})$.

MACE was defined as an outcome parameter i.e. cardiovascular death, nonfatal myocardial infarction, coronary by- 

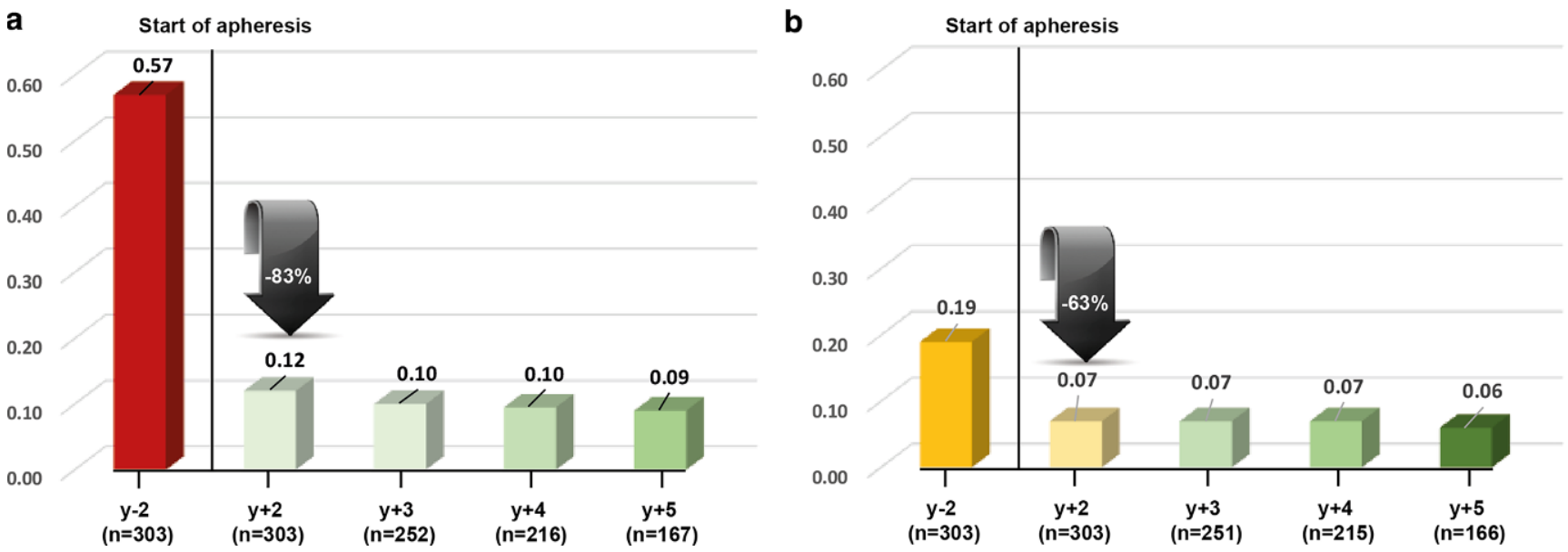

Fig. 1 Seven-year course of German Lipoprotein Apheresis Registry (GLAR) data with respect to a major adverse cardiac events (MACE) or b major adverse non-cardiac events (MANCE). The database interrogation used the terms $\mathrm{Lp}(\mathrm{a})>60 \mathrm{mg} / \mathrm{dl}(>120 \mathrm{nmol} / \mathrm{l})$ and LDL-C $<100 \mathrm{mg} / \mathrm{dl}$ $(<2.6 \mathrm{mmol} / \mathrm{l})$

pass surgery, percutaneous coronary intervention, or stent, whereas MANCE was determined as non-cardiovascular events i.e. stroke, carotid percutaneous transluminal angioplasty or carotid surgery or peripheral vascular events (peripheral vascular event of lower extremities or renal arteries with percutaneous transluminal angioplasty, stent, bypass surgery, amputation), or venous thrombotic events like deep venous thrombosis or pulmonary embolism.

The access, database, quality, entries, queries, and evaluation of the German Lipoprotein Apheresis Registry (GLAR) were described previously [18].

\section{Results}

Data of more than 26,977 LA treatments of 1632 patients were entered into GLAR, mostly 1 to 2 treatments per quarter. All required data are available for each patient as the design of the entry form requires complete data collection.

From 2012 to 2017, 79 German apheresis centers collected retrospective and prospective observational data of 1632 patients undergoing LA to treat high LDL-C levels and/or high $\mathrm{Lp}$ (a) levels, who were suffering from progressive cardiovascular disease (CVD).

Analog to the pattern of the Pro(a)LiFe study, Lp(a) patient data $(\mathrm{Lp}(\mathrm{a})>60 \mathrm{mg} / \mathrm{dl} \quad(>120 \mathrm{nmol} / \mathrm{l}) ; \quad$ LDL-C $<$ $100 \mathrm{mg} / \mathrm{dl} \quad(<2.6 \mathrm{mmol} / \mathrm{l})$ were analyzed with respect to incidence rates of major coronary events (MACE) 2 years before and prospectively for 2-5 years undergoing chronic LA treatment. Patients with available data according to the query pattern in the period 2012-2017 were found to have a reduction in MACE of $83 \%$ (Fig. 1a). The same query scheme was applied for major non-coronary events (MANCE) (Fig. 1b). An average reduction rate of MANCE of $63 \%$ was observed.

\section{Discussion}

Now there is more evidence that elevated $\mathrm{Lp}$ (a) levels may contribute to ASCVD and CAVS. Although Lp(a) isoformindependent assays are available, it is still being discussed, which $\mathrm{Lp}$ (a) measurement method is the gold standard, and consequently which units ( $\mathrm{mg} / \mathrm{dl}$ or $\mathrm{nmol} / \mathrm{l}) \mathrm{Lp}$ (a) should be given in $[5,19]$. Furthermore, a clear linear association of $L p(a)$ levels and the risk for ASCVD is missing, which could be measured in patients with different LDL-cholesterol (LDL-C) levels. With respect to the given uncertainty of $L p(a)$ measurement it may be useful that levels should not be given in metric units but in qualitative statements like normal level and cardiovascular risk, or high level and increased risk for ASCVD.

However, based on interaction with genetic, epidemiological, translational, and pathophysiological insights, Lp(a) is established as an independent genetic, and likely causal risk factor for ASCVD and CAVS [20].

In a broad spectrum of patients these observations are consistent across risk factors and concomitant therapies. Until now there is a huge demand for reducing $\operatorname{Lp}(a)$, but no investigations using lipid-lowering drugs had shown that further cardiovascular events (CVE) could be reduced. Statins tend to increase $\mathrm{Lp}$ (a) levels, but it is never been investigated if this effect is clinically relevant. Recently approved proprotein convertase subtilisin/kexin-type 9 inhibitors (PCSK9i) and mipomersen lower Lp(a) 20-30\%, and RNA-targeted therapies lower Lp(a) levels $>80 \%$ [21]. But these approaches have not been tested in clinical outcome trials. A current investigation demonstrates for PCSK9i again an impressive LDL-C reduction and a minor $\mathrm{Lp}$ (a) reduction when $\mathrm{Lp}(\mathrm{a})>80 \mathrm{mg} / \mathrm{dl}(>200 \mathrm{nmol} / \mathrm{l})$. But this persistent small decrease of $\mathrm{Lp}(\mathrm{a})$ may have contributed 


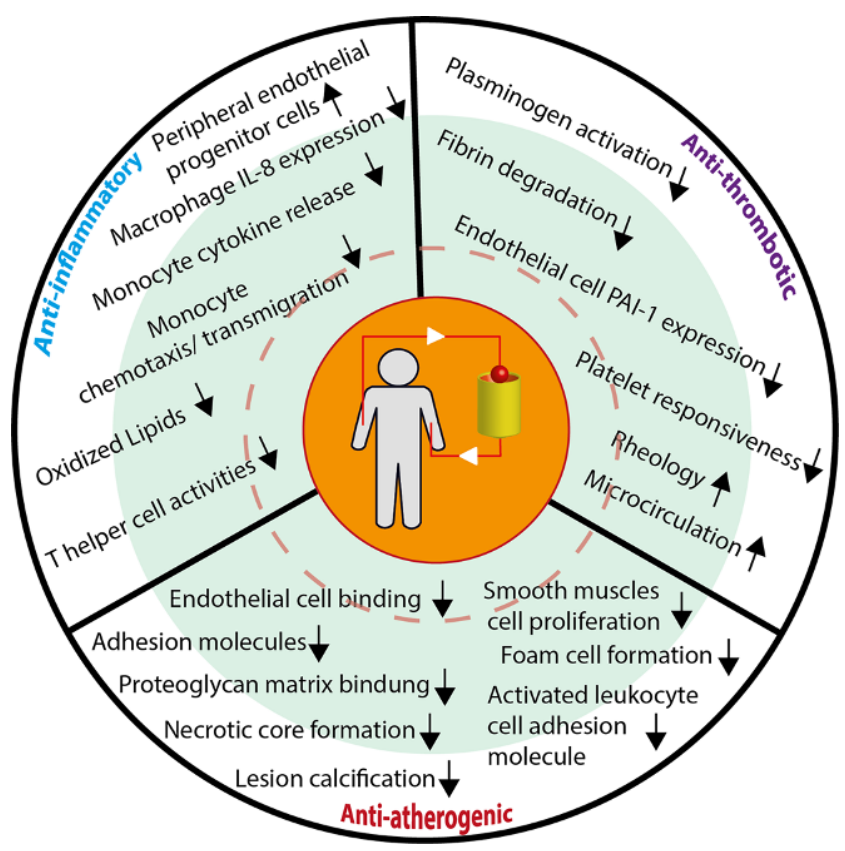

Fig. 2 The complex effect of lipoprotein apheresis (LA) on the atherogenicity of $\mathrm{Lp}(\mathrm{a})$, which was classified in 3 categories: pro-inflammatory, pro-thrombotic, and therefore pro-atherogenic [2, 41-44]. The given parameters are only examples, the influence of LA on blood components is far-ranging

to the observation that lipid lowering by PCSK9i did not lead to a reduction in arterial wall inflammation [22].

Lipoprotein apheresis (LA) therapy is with respect to $\mathrm{Lp}$ (a) levels only indicated when high $\mathrm{Lp}$ (a) levels $(>60 \mathrm{mg} / \mathrm{dl}(120 \mathrm{nmol} / \mathrm{l}))$ in combination with normal LDLC levels $(<100 \mathrm{mg} / \mathrm{dl}(<1.8 \mathrm{mmol} / \mathrm{l}))$ induced progressive cardiovascular damage. The acute decrease of $\mathrm{Lp}(\mathrm{a})$ levels by LA is impressive, mostly more than $70 \%$ after LA treatment. Prevention of cardiovascular complications in patients with high $\mathrm{Lp}(\mathrm{a})$ and progressive cardiovascular disease by long-term LA was shown in the Pro(a) $\mathrm{LiFe}$ investigation. From the first year under chronic LA treatment the MACE and MANCE rates could be reduced significantly. This early CVE reduction was not shown in any other lipid-lowering drug investigations with respect of high Lp(a) levels and ASCVD. However, the recent database interrogation of GLAR using nearly the same Pro(a)LiFe study settings confirm these important findings and showed a similar and constant reduction of MACE and MANCE in Lp(a) patients undergoing regular LA for up to 5 years of treatment.

But how could these impressive findings be explained? $\mathrm{Lp}$ (a) can be a major pro-inflammatory, pro-thrombotic, or atherosclerotic risk factor [5]. Individuals might start developing an atherosclerotic process due to other risk factors like high LDL-C levels, hypertension, smoking, or chronic inflammatory diseases like rheumatoid arthritis. Furthermore, the immune system plays a crucial role in the pro- gression and modulation of atherosclerosis [23, 24]. T cells that respond to autoantigenic components of LDL or Lp(a) particles orchestrate plaque development [25]. Many connections between the immune system and metabolism exist; acute inflammation induces hypertriglyceridemia [26], whereas chronic inflammation in the arterial walls has more complex effects, like in rheumatoid arthritis [27]. Novel approaches such as anti-inflammatory therapies like the CANTOS trial [13, 14], T-cell-based treatments or vaccination against LDL or Lp(a) [28] could potentially reduce cardiovascular inflammation and protect against the development of atherosclerosis [29-31]. In addition cell-cell communication is important to maintain the inflammatory settings [32]. Because of the human individual immune reactivity to high levels of LDL-C or Lp(a) the difference of atherosclerotic lesion development may be explainable, e.g. in some cases high levels of $L p(a)$ induce no, in other cases moderate $\mathrm{Lp}(\mathrm{a})$ levels fulminate ASCVD.

However, it is becoming more and more evident that LA could not only reduce LDL-C or Lp(a) levels (Fig. 2). LA improves whole blood viscosity and endothelium-mediated vasodilation, and has a positive effect on the hemorheological composition, improving perfusion in the microcirculation [33]. Recently in a randomized controlled cross-over trial in patients with refractory angina and increased $\mathrm{Lp}$ (a) levels, myocardial perfusion, atheroma burden, exercise capacity and symptoms were found to be improved with LA treatment [34]. In addition LA changes the plasma inflammatory profile and the cytokine pattern in patients with severe dyslipidemia, which may correspond to the early reduction of MACE and MANCE in Lp(a) patients [15, $17,35,36]$. Because of its assumed long circulation in the arterial vessels $\mathrm{Lp}$ (a) contains pro-inflammatory oxidized phospholipids (OxPL), which induce monocyte trafficking to the arterial wall and mediate pro-inflammatory responses through its OxPL content [32]. In patients undergoing regular LA decreased OxPL levels could be determined after treatment [37].

Elevated $\mathrm{Lp}$ (a) could be also involved in atherothrombotic disorders. $\mathrm{Lp}(\mathrm{a})$ influences different coagulation factors resulting in thrombus formation [38]. Patients suffering from thrombophilia $\mathrm{Lp}(\mathrm{a})$ may aggravate the coagulation situation, leading e.g. to placenta-mediated pregnancy complications resulting in early miscarriages [39, 40].

In summary regular LA treatment may break the vicious circle of atherosclerosis induced by $\operatorname{Lp}$ (a) because of its multifactorial influence on this pathophysiology (Fig. 2). LA is therefore anti-atherosclerotic, anti-inflammatory, anti-thrombotic, and consequently an optimal therapeutic option to reduce increased $\mathrm{Lp}$ (a) levels.

Acknowledgements The authors appreciate the dedicated help and time of the colleagues and members of the scientific board of GLAR, 
Germany: A. Vogt (Munich), B.R. Jaeger (Mühlheim), F. van Buuren (Oelpe), K.P. Mellwig (Bad Oeynhausen), H.U. Klör (Gießen), P. Grützmacher (Frankfurt), E. Roeseler (Hannover), U. Julius (Dresden), B. Hohenstein (Villingen-Schwenningen), F. Heigl (Kempten), H. Blume (Düsseldorf), R. Klingel (Köln), and V.J.J. Schettler (Göttingen).

Conflict of interest V.J.J. Schettler, C.L. Neumann, C. Peter, T. Zimmermann, U. Julius, B. Hohenstein, E. Roeseler, F. Heigl, P. Grützmacher, H. Blume, R. Klingel, A. Vogt declare that they have no competing interests.

Open Access This article is distributed under the terms of the Creative Commons Attribution 4.0 International License (http:// creativecommons.org/licenses/by/4.0/), which permits unrestricted use, distribution, and reproduction in any medium, provided you give appropriate credit to the original author(s) and the source, provide a link to the Creative Commons license, and indicate if changes were made.

\section{Literature}

1. Yusuf S, Hawken S, Ounpuu S, Dans T, Avezum A, Lanas F, McQueen M, Budaj A, Pais P, Varigos J, Lisheng L, Investigators IS (2004) Effect of potentially modifiable risk factors associated with myocardial infarction in 52 countries (the INTERHEART study): case-control study. Lancet 364(9438):937-952. https://doi.org/10. 1016/S0140-6736(04)17018-9

2. Tsimikas S (2017) A test in context: lipoprotein(a): diagnosis, prognosis, controversies, and emerging therapies. J Am Coll Cardiol 69(6):692-711. https://doi.org/10.1016/j.jacc.2016.11.042

3. Nordestgaard BG, Langsted A (2016) Lipoprotein (a) as a cause of cardiovascular disease: insights from epidemiology, genetics, and biology. J Lipid Res 57(11):1953-1975. https://doi.org/10.1194/jlr. R071233

4. Nordestgaard BG, Chapman MJ, Ray K, Boren J, Andreotti F, Watts GF, Ginsberg H, Amarenco P, Catapano A, Descamps OS, Fisher E, Kovanen PT, Kuivenhoven JA, Lesnik P, Masana L, Reiner Z, Taskinen MR, Tokgozoglu L, Tybjaerg-Hansen A, European Atherosclerosis Society Consensus P (2010) Lipoprotein(a) as a cardiovascular risk factor: current status. Eur Heart J 31(23):2844-2853. https:// doi.org/10.1093/eurheartj/ehq386

5. Marcovina SM, Moriarty PM, Koschinsky ML, Guyton JR (2018) JCL roundtable-lipoprotein(a): the emerging risk factor. J Clin Lipidol 12(6):1335-1345. https://doi.org/10.1016/j.jacl.2018.11.003

6. Willeit P, Ridker PM, Nestel PJ, Simes J, Tonkin AM, Pedersen TR, Schwartz GG, Olsson AG, Colhoun HM, Kronenberg F, Drechsler C, Wanner C, Mora S, Lesogor A, Tsimikas S (2018) Baseline and on-statin treatment lipoprotein(a) levels for prediction of cardiovascular events: individual patient-data meta-analysis of statin outcome trials. Lancet 392(10155):1311-1320. https://doi.org/10. 1016/S0140-6736(18)31652-0

7. Parhofer KG (2009) Review of extended-release niacin/laropiprant fixed combination in the treatment of mixed dyslipidemia and primary hypercholesterolemia. Vasc Health Risk Manag 5:901-908

8. Albers JJ, Slee A, O'Brien KD, Robinson JG, Kashyap ML, Kwiterovich PO Jr., Xu P, Marcovina SM (2013) Relationship of apolipoproteins A-1 and B, and lipoprotein(a) to cardiovascular outcomes: the AIM-HIGH trial (Atherothrombosis Intervention in Metabolic Syndrome with Low HDL/High Triglyceride and Impact on Global Health Outcomes). J Am Coll Cardiol 62(17):1575-1579. https://doi.org/10.1016/j.jacc.2013.06.051

9. Sabatine MS, Giugliano RP, Keech AC, Honarpour N, Wiviott SD, Murphy SA, Kuder JF, Wang H, Liu T, Wasserman SM, Sever PS, Pedersen TR, Committee FS, Investigators (1722) Evolocumab and clinical outcomes in patients with cardiovascular disease. N Engl J Med 376(18):1713. https://doi.org/10.1056/NEJMoa1615664

10. Schwartz GG, Steg PG, Szarek M, Bhatt DL, Bittner VA, Diaz R, Edelberg JM, Goodman SG, Hanotin C, Harrington RA, Jukema JW, Lecorps G, Mahaffey KW, Moryusef A, Pordy R, Quintero K, Roe MT, Sasiela WJ, Tamby JF, Tricoci P, White HD, Zeiher AM, Committees OO, Investigators (2018) Alirocumab and cardiovascular outcomes after acute coronary syndrome. N Engl J Med 379(22):2097-2107. https://doi.org/10.1056/NEJMoa1801174

11. Toth PP, Worthy G, Gandra SR, Sattar N, Bray S, Cheng LI, Bridges I, Worth GM, Dent R, Forbes CA, Deshpande S, Ross J, Kleijnen J, Stroes ESG (2017) Systematic review and network meta-analysis on the efficacy of evolocumab and other therapies for the management of lipid levels in hyperlipidemia. J Am Heart Assoc. https:// doi.org/10.1161/JAHA.116.005367

12. Schettler V, Neumann CL, Hulpke-Wette M, Hagenah GC, Schulz EG, Wieland E, German Apheresis Working G (2012) Current view: indications for extracorporeal lipid apheresis treatment. Clin Res Cardiol Suppl 7:15-19. https://doi.org/10.1007/s11789-0120046-6

13. Ridker PM, Everett BM, Thuren T, MacFadyen JG, Chang WH, Ballantyne C, Fonseca F, Nicolau J, Koenig W, Anker SD, Kastelein JJP, Cornel JH, Pais P, Pella D, Genest J, Cifkova R, Lorenzatti A, Forster T, Kobalava Z, Vida-Simiti L, Flather M, Shimokawa H, Ogawa H, Dellborg M, Rossi PRF, Troquay RPT, Libby P, Glynn RJ, Group CT (2017) Antiinflammatory therapy with canakinumab for atherosclerotic disease. N Engl J Med 377(12):1119-1131. https://doi.org/10.1056/NEJMoa1707914

14. Back M, Hansson GK (2015) Anti-inflammatory therapies for atherosclerosis. Nat Rev Cardiol 12(4):199-211. https://doi.org/10. 1038/nrcardio. 2015.5

15. Wieland E, Schettler V, Armstrong VW (2002) Highly effective reduction of C-reactive protein in patients with coronary heart disease by extracorporeal low density lipoprotein apheresis. Atherosclerosis 162(1):187-191

16. Julius U, Siegert G, Kostka H, Schatz U, Hohenstein B (2015) Effects of different lipoprotein apheresis methods on serum protein levels. Atheroscler Suppl 18:95-102. https://doi.org/10.1016/j. atherosclerosissup.2015.02.018

17. Roeseler E, Julius U, Heigl F, Spitthoever R, Heutling D, Breitenberger P, Leebmann J, Lehmacher W, Kamstrup PR, Nordestgaard BG, Maerz W, Noureen A, Schmidt K, Kronenberg F, Heibges A, Klingel R, ProLiFe-Study G (2016) Lipoprotein apheresis for lipoprotein(a)-associated cardiovascular disease: prospective 5 years of follow-up and apolipoprotein(a) characterization. Arterioscler Thromb Vasc Biol 36(9):2019-2027. https://doi.org/10. 1161/ATVBAHA.116.307983

18. Schettler VJJ, Neumann CL, Peter C, Zimmermann T, Julius U, Roeseler E, Heigl F, Grutzmacher P, Blume H, Scientific Board of GftGAWG (2017) Current insights into the German Lipoprotein Apheresis Registry (GLAR)—Almost 5 years on. Atheroscler Suppl 30:50-55. https://doi.org/10.1016/j.atherosclerosissup.2017. 05.006

19. Tsimikas S, Fazio S, Viney NJ, Xia S, Witztum JL, Marcovina SM (2018) Relationship of lipoprotein(a) molar concentrations and mass according to lipoprotein(a) thresholds and apolipoprotein(a) isoform size. J Clin Lipidol 12(5):1313-1323. https://doi.org/10. 1016/j.jacl.2018.07.003

20. Capoulade R, Yeang C, Chan KL, Pibarot P, Tsimikas S (2018) Association of mild to moderate aortic valve Stenosis progression with higher lipoprotein(a) and oxidized phospholipid levels: secondary analysis of a randomized clinical trial. JAMA Cardiol. https://doi. org/10.1001/jamacardio.2018.3798

21. Tsimikas S (2016) Lipoprotein(a): novel target and emergence of novel therapies to lower cardiovascular disease risk. Curr Opin 
Endocrinol Diabetes Obes 23(2):157-164. https://doi.org/10.1097/ MED.0000000000000237

22. Stiekema LCA, Stroes ESG, Verweij SL, Kassahun H, Chen L, Wasserman SM, Sabatine MS, Mani V, Fayad ZA (2018) Persistent arterial wall inflammation in patients with elevated lipoprotein(a) despite strong low-density lipoprotein cholesterol reduction by proprotein convertase subtilisin/kexin type 9 antibody treatment. Eur Heart J. https://doi.org/10.1093/eurheartj/ehy862

23. Winkels H, Ehinger E, Ghosheh Y, Wolf D, Ley K (2018) Atherosclerosis in the single-cell era. Curr Opin Lipidol 29(5):389-396. https://doi.org/10.1097/MOL.0000000000000537

24. Gistera A, Hansson GK (2017) The immunology of atherosclerosis. Nat Rev Nephrol 13(6):368-380. https://doi.org/10.1038/nrneph. 2017.51

25. Madhur MS, Funt SA, Li L, Vinh A, Chen W, Lob HE, Iwakura Y, Blinder Y, Rahman A, Quyyumi AA, Harrison DG (2011) Role of interleukin 17 in inflammation, atherosclerosis, and vascular function in apolipoprotein e-deficient mice. Arterioscler Thromb Vasc Biol 31(7):1565-1572. https://doi.org/10.1161/ATVBAHA. 111.227629

26. Sammalkorpi K, Valtonen V, Kerttula Y, Nikkila E, Taskinen MR (1988) Changes in serum lipoprotein pattern induced by acute infections. Metabolism 37(9):859-865

27. Holmqvist ME, Wedren S, Jacobsson LT, Klareskog L, Nyberg F, Rantapaa-Dahlqvist S, Alfredsson L, Askling J (2010) Rapid increase in myocardial infarction risk following diagnosis of rheumatoid arthritis amongst patients diagnosed between 1995 and 2006. J Intern Med 268(6):578-585. https://doi.org/10.1111/j.1365-2796. 2010.02260.x

28. Fredrikson GN, Soderberg I, Lindholm M, Dimayuga P, Chyu KY, Shah PK, Nilsson J (2003) Inhibition of atherosclerosis in apoEnull mice by immunization with apoB-100 peptide sequences. Arterioscler Thromb Vasc Biol 23(5):879-884. https://doi.org/10.1161/ 01.ATV.0000067937.93716.DB

29. Schiopu A, Bengtsson J, Soderberg I, Janciauskiene S, Lindgren S, Ares MP, Shah PK, Carlsson R, Nilsson J, Fredrikson GN (2004) Recombinant human antibodies against aldehyde-modified apolipoprotein B-100 peptide sequences inhibit atherosclerosis. Circulation 110(14):2047-2052. https://doi.org/10.1161/01.CIR. 0000143162.56057.B5

30. Libby P, Loscalzo J, Ridker PM, Farkouh ME, Hsue PY, Fuster V, Hasan AA, Amar S (2018) Inflammation, Immunity, and Infection in Atherothrombosis: JACC Review Topic of the Week. J Am Coll Cardiol 72(17):2071-2081. https://doi.org/10.1016/j.jacc.2018.08. 1043

31. Orso E, Schmitz G (2017) Lipoprotein(a) and its role in inflammation, atherosclerosis and malignancies. Clin Res Cardiol Suppl 12(Suppl 1):31-37. https://doi.org/10.1007/s11789-017-0084-1

32. van der Valk FM, Bekkering S, Kroon J, Yeang C, Van den Bossche J, van Buul JD, Ravandi A, Nederveen AJ, Verberne HJ, Scipione C, Nieuwdorp M, Joosten LA, Netea MG, Koschinsky ML, Witztum JL, Tsimikas S, Riksen NP, Stroes ES (2016) Oxidized phospholipids on lipoprotein(a) elicit arterial wall inflammation and an inflammatory monocyte response in humans. Circulation 134(8):611-624. https://doi.org/10.1161/CIRCULATIONAHA. 116.020838
33. Ramunni A, Burzo M, Verno L, Brescia P (2009) Pleiotropic effects of LDL apheresis. Atheroscler Suppl 10(5):53-55. https://doi.org/ 10.1016/S1567-5688(09)71811-2

34. Khan TZ, Hsu LY, Arai AE, Rhodes S, Pottle A, Wage R, Banya W, Gatehouse PD, Giri S, Collins P, Pennell DJ, Barbir M (2017) Apheresis as novel treatment for refractory angina with raised lipoprotein(a): a randomized controlled cross-over trial. Eur Heart J 38(20):1561-1569. https://doi.org/10.1093/eurheartj/ehx178

35. Leebmann J, Roeseler E, Julius U, Heigl F, Spitthoever R, Heutling D, Breitenberger P, Maerz W, Lehmacher W, Heibges A, Klingel R, ProLiFe Study G (2013) Lipoprotein apheresis in patients with maximally tolerated lipid-lowering therapy, lipoprotein(a)-hyperlipoproteinemia, and progressive cardiovascular disease: prospective observational multicenter study. Circulation 128(24):2567-2576. https://doi.org/10.1161/CIRCULATIONAHA. 113.002432

36. von Bauer R, Oikonomou D, Sulaj A, Kopf S, Fleming T, Rudofsky G, Nawroth P (2018) Pleiotropic effect of lipoprotein-apheresis on the soluble form of activated leukocyte cell adhesion molecule (sALCAM) in familial hypercholesterolaemia. Exp Clin Endocrinol Diabetes. https://doi.org/10.1055/a-0630-0232

37. Arai K, Orsoni A, Mallat Z, Tedgui A, Witztum JL, Bruckert E, Tselepis AD, Chapman MJ, Tsimikas S (2012) Acute impact of apheresis on oxidized phospholipids in patients with familial hypercholesterolemia. J Lipid Res 53(8):1670-1678. https://doi.org/ 10.1194/jlr.P027235

38. Ferretti G, Bacchetti T, Johnston TP, Banach M, Pirro M, Sahebkar A (2018) Lipoprotein(a): a missing culprit in the management of athero-thrombosis? J Cell Physiol 233(4):2966-2981. https://doi. org/10.1002/jcp. 26050

39. Schettler VJ, Schulz EG, Hagenah GC, Neumann CL (2014) Successful completion of pregnancy using apheresis and a balanced dose of coagulation factors in the presence of high thrombophilia and $\mathrm{Lp}$ (a) levels in a woman with two previous abortions. Clin Kidney J 7(5):497-498. https://doi.org/10.1093/ckj/sfu083

40. Romagnuolo I, Sticchi E, Attanasio M, Grifoni E, Cioni G, Cellai AP, Abbate R, Fatini C (2016) Searching for a common mechanism for placenta-mediated pregnancy complications and cardiovascular disease: role of lipoprotein(a). Fertil Steril 105(5):1287-1293. https://doi.org/10.1016/j.fertnstert.2016.01.014

41. Patschan D, Patschan S, Henze E, Wessels JT, Koziolek M, Muller GA (2009) LDL lipid apheresis rapidly increases peripheral endothelial progenitor cell competence. J Clin Apher 24(5):180-185. https://doi.org/10.1002/jca.20208

42. Mellwig KP, Pulawski E, Horstkotte D, van Buuren F (2012) Lipid apheresis: oxidative stress, rheology, and vasodilatation. Clin Res Cardiol Suppl 7:45-49. https://doi.org/10.1007/s11789-012-00439

43. Wieland E, Schettler V, Creutzfeldt C, Kickbusch H, Schuff-Werner $P$ (1995) Lack of plasma lipid peroxidation during LDL-apheresis by heparin-induced extracorporeal LDL-precipitation. Eur J Clin Invest 25(11):838-842

44. Schettler V, Methe H, Schuff-Werner P, Muller GA, Wieland E (2000) Acute effect of H.E.L.P. treatment on radical scavenging enzyme activities, total glutathione concentrations in granulocytes, and selenium in plasma. Eur J Clin Invest 30(1):26-32 